\title{
Soil Organic Matter Fractions Under Eucalypt Plantation in Reform Management
}

\author{
Emanuelle Merces Barros Soares ${ }^{1}$ (D), Rafael da Silva Teixeira ${ }^{1}$ (D), \\ Rodrigo Nogueira de Sousa ${ }^{1}$ (D), Aline de Almeida Vasconcelos ${ }^{1}$ (D), \\ Ivo Ribeiro da Silva ${ }^{1}$ \\ ${ }^{1}$ Departamento de Solos, Universidade Federal de Viçosa - UFV, Viçosa/MG, Brasil
}

\begin{abstract}
Harvesting and reform in eucalyptus can lead to changes in soil organic matter (SOM). The objective of this work was to evaluate the changes in total organic C (TOC) and N (NT), C and N in humic acid (HA), fulvic acid (FH), light organic matter (LOM) and microbial biomass (MB), in Ultisol of eucalypt stands over one, two and four years of renovated areas in Rio Grande do Sul state. After the first year of eucalyptus reform, there were $78 \%$ of increases in TOC $(0.0-1.0-\mathrm{m}$ soil layer). After two years, there was an increase in $\mathrm{TN}$ and an average reduction of $52 \%$ in LOM-C (0.0-0.1-m soil layer). FA-C, HA-C, and HU-C presented mean reductions of $43 \mathrm{Mg} \mathrm{ha}^{-1}$ (0.0-1.0-m soil layer) after four years of reform. The litter contribution of previous crop and the crop residues from the harvest resulted in increments of the SOM fractions. However, there is a negative effect in later years.
\end{abstract}

Keywords: forest soils, reform, humic substances, microbial biomass, light organic matter. 


\section{INTRODUCTION}

In the last decades, the global growing demand for forest products (FAO, 2010) has promoted the expansion of cultivated areas with eucalypt. In Brazil, the total area of planted forests in 2015 reached 7.8 million hectares, in which 5.6 million hectares are eucalypts mainly distributed in the states of Minas Gerais (24\%), São Paulo (17\%), and Mato Grosso do Sul (15\%) (IBÁ, 2016). This expressive planted area occurs due to the favorable conditions over almost the whole country to the rapid eucalypt growing, which has provided shorter rotations, between five and seven years.

When conducted under reform management, the eucalypt plantation promotes impact due to harvesting and wood drag, additional soil disturbance occurs due to the mechanical preparation for the new planting. Such disturbances are related to soil compaction and disaggregation, and the incorporation of residues and organic horizons into the soil mass of the prepared region. Exposure of the soil to the sun and rain also causes alterations in the humidity and temperature, besides lower water infiltration rate and a greater predisposition to erosion (Dias et al., 2007; Oliveira et al., 2013). These abiotic factors combination alters the biological activity and soil structure (Ndaw et al., 2009), with potential effects on soil organic matter (SOM) dynamics and sequestration. In temperate forests has been often observed that soil $\mathrm{CO}_{2}$ fluxes increase, and $\mathrm{SOM}$ decreases after harvesting operations (Chatterjee et al., 2008; Amiro et al., 2000). Still, negative effects seem to be minimized when only the wood is removed from the area (Strömgren et al., 2013; Versini et al., 2013).

However, the impacts of harvesting and reforming eucalypt plantations, especially in tropical and subtropical regions, are still poorly understood. In Brazil, losses of SOM induced during the reform management were compensated by a large input of harvest residues, also by strains of previous eucalypt plantation (Faria et al., 2008; Nave et al., 2010; Jesus et al., 2015).

Thus, the introduction of eucalypt plantations in areas under native vegetation would initially result in reductions of total $\mathrm{C}$ and $\mathrm{N}$ stocks, which could be recovered throughout the eucalypt cultivation, depending on the type of management to be conducted. So, the objectives of this work were: i) to evaluate the change in the total $\mathrm{C}$ and $\mathrm{N}$ stocks and their compartments in soils under eucalypt plantations with different ages after the reform management, which was established under native vegetation area; ii) to evaluate the changes in labile and stable SOM fractions in variable times after the reform management of eucalypt plantations implanted in native vegetation area.

\section{MATERIAL AND METHODS}

The study was carried out in commercial eucalypt plantations (Eucalyptus grandis) in the municipality of Triunfo (29 $56^{\prime} \mathrm{S}$ and $51^{\circ} 43^{\prime} \mathrm{W}$ ), east of Rio Grande do Sul state, in the Colorado Forest plantation. The climate of the region is classified as Humid Subtropical (Köppen climate classification: Cfa) (Moreno, 1961). The region has annual average temperature of $16.5^{\circ} \mathrm{C}$ and annual rainfall around 1,300 to $1,800 \mathrm{~mm}$ (Maluf, 2000).

Eucalypt plantations were selected under an Ultisol following a planting chronosequence aiming to evaluate the effect of time, after reform management of eucalypt plantations at age of 13-years-old (first rotation). The previous use before eucalypt plantation in all areas was native vegetation. The soil samples were collected in native vegetation, 13-year-old unreformed eucalypt plantation (considered as zero reform time), also in eucalypt plantations reformed of one, two and four years ago.

In each soil use, four plots of $50 \times 50 \mathrm{~cm}$ (considered as four replications) were delimited. Five subsamples were collected in each plot in the layers 0.0-0.1, $0.1-0.2,0.2-0.4,0.4-0.6,0.6-1.0-\mathrm{m}$ to compose the composite sample. In addition, a trench of $1.2-\mathrm{m}$ depth was excavated in each plot to collect undisturbed samples. Chemical and physical characteristics are in Tables 1 and 2, respectively.

Total organic carbon (TOC) was determined using the method described by Yeomans \& Bremner (1988) and Total nitrogen (TN) by the Kjeldhal method modified by Tedesco et al. (1985). The humic substances fractions (HS) were obtained by chemical fractionation (Swift, 1996). The light organic matter (LOM) was determined following the procedure proposed by Sohi et al. (2001). The $\mathrm{C}$ and $\mathrm{N}$ associated with microbial biomass (C-MB and $\mathrm{N}-\mathrm{MB}$ ) were obtained by the irradiation-extraction method (Islam \& Weil, 1998).

The $\mathrm{C}$ and $\mathrm{N}$ stocks associated with soil organic matter fractions (SOM) were obtained multiplying 
Table 1. Chemical characterization of samples from Ultisol under different uses, in the 0.0-0.1-m soil layer, east of Rio Grande do Sul state.

\begin{tabular}{|c|c|c|c|c|c|c|c|c|}
\hline \multirow{2}{*}{ Land use } & $\mathrm{pH}$ & $\mathrm{Ca}$ & Mg & Al & $\mathbf{H}+\mathbf{A l}$ & $\mathbf{P}$ & $\mathbf{K}$ & \multirow{2}{*}{$\frac{\mathrm{CEC}_{\mathrm{pH} 7.0}}{\mathrm{cmol}_{\mathrm{c}} \mathrm{dm}^{-3}}$} \\
\hline & \multicolumn{5}{|c|}{ 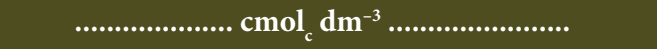 } & \multicolumn{2}{|c|}{$\ldots . . \mathrm{mg} \mathrm{dm}^{-3} \ldots$} & \\
\hline Native Vegetation & 4.59 & 0.81 & 0.83 & 1.89 & 5.79 & 3.23 & 43.21 & 7.43 \\
\hline Euc R0 & 4.45 & 2.39 & 1.34 & 2.02 & 7.25 & 7.33 & 153.29 & 10.98 \\
\hline Euc R1 & 4.16 & 0.13 & 0.29 & 4.29 & 11.30 & 10.15 & 113.35 & 11.72 \\
\hline Euc R2 & 4.05 & 0.35 & 0.43 & 4.54 & 8.87 & 14.31 & 55.19 & 9.65 \\
\hline Euc R4 & 4.25 & 1.27 & 0.81 & 2.90 & 6.60 & 13.17 & 105.36 & 8.68 \\
\hline
\end{tabular}

Euc R0 = Eucalypt plantations unreformed with 13 years old; Euc R1 = Eucalypt plantations reformed one year ago; Euc R2 = Eucalypt

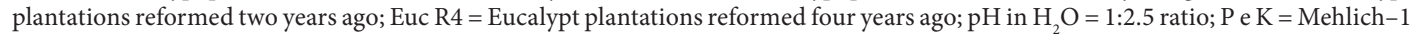
extractor; $\mathrm{Ca}, \mathrm{Mg}$ and $\mathrm{Al}=\mathrm{KCl} 1 \mathrm{~mol} \mathrm{~L}^{-1}$ extractor; $\mathrm{H}+\mathrm{Al}=$ Calcium acetate $0.5 \mathrm{~mol} \mathrm{~L}^{-1}$ at $\mathrm{pH} 7.0$ extractor; $\mathrm{CEC}=$ cation exchange capacity measured with $0.5 \mathrm{~mol} \mathrm{~L}^{-1}$ calcium acetate at $\mathrm{pH}$ 7.0.

Table 2. Composition of particle size from Ultisol under native vegetation and eucalypt plantations of different ages and times after reform management.

\begin{tabular}{|c|c|c|c|c|c|}
\hline \multirow{2}{*}{ Land Use } & Soil Layer & Sand & Silt & Clay & \multirow{2}{*}{$\begin{array}{c}\text { Ds } \\
\ldots . . . \mathrm{kg} \mathrm{dm}^{-3} \ldots .\end{array}$} \\
\hline & ........ m ........ & \multicolumn{3}{|c|}{.................. g kg $^{-1}$} & \\
\hline \multirow{5}{*}{ Native vegetation } & $0.0-0.1$ & 450.00 & 160.00 & 390.00 & 1.01 \\
\hline & $0.1-0.2$ & 450.00 & 150.00 & 400.00 & 0.86 \\
\hline & $0.2-0.4$ & 380.00 & 150.00 & 470.00 & 0.78 \\
\hline & $0.4-0.6$ & 370.00 & 120.00 & 510.00 & 0.76 \\
\hline & $0.6-1.0$ & 340.00 & 130.00 & 530.00 & 1.31 \\
\hline \multirow{5}{*}{ Euc R0 } & $0.0-0.1$ & 380.00 & 200.00 & 420.00 & 0.69 \\
\hline & $0.1-0.2$ & 440.00 & 170.00 & 390.00 & 0.72 \\
\hline & $0.2-0.4$ & 540.00 & 200.00 & 260.00 & 0.99 \\
\hline & $0.4-0.6$ & 590.00 & 160.00 & 250.00 & 1.08 \\
\hline & $0.6-1.0$ & 520.00 & 200.00 & 280.00 & 1.17 \\
\hline \multirow{6}{*}{ Euc R1 } & $0.0-0.1$ & 310.00 & 140.00 & 550.00 & 1.01 \\
\hline & $0.1-0.2$ & 300.00 & 120.00 & 580.00 & 1.04 \\
\hline & $0.2-0.4$ & 350.00 & 80.00 & 570.00 & 0.77 \\
\hline & $0.4-0.6$ & 280.00 & 90.00 & 630.00 & 0.79 \\
\hline & $0.6-1.0$ & 190.00 & 110.00 & 700.00 & 0.71 \\
\hline & $0.0-0.1$ & 490.00 & 180.00 & 330.00 & 0.87 \\
\hline \multirow{5}{*}{ Euc R2 } & $0.1-0.2$ & 450.00 & 170.00 & 380.00 & 0.84 \\
\hline & $0.2-0.4$ & 440.00 & 180.00 & 380.00 & 0.96 \\
\hline & $0.4-0.6$ & 420.00 & 160.00 & 420.00 & 0.93 \\
\hline & $0.6-1.0$ & 410.00 & 160.00 & 430.00 & 0.83 \\
\hline & $0.0-0.1$ & 460.00 & 110.00 & 430.00 & 1.07 \\
\hline \multirow{4}{*}{ Euc R4 } & $0.1-0.2$ & 440.00 & 90.00 & 470.00 & 1.02 \\
\hline & $0.2-0.4$ & 270.00 & 110.00 & 620.00 & 0.88 \\
\hline & $0.4-0.6$ & 190.00 & 170.00 & 640.00 & 0.77 \\
\hline & $0.6-1.0$ & 190.00 & 210.00 & 600.00 & 0.84 \\
\hline
\end{tabular}

Ds = Soil bulk density; Euc R0 = Eucalypt plantations unreformed with 13 years old; Euc R1 = Eucalypt plantations reformed one year ago; Euc R2 = Eucalypt plantations reformed two years ago; Euc R4 = Eucalypt plantations reformed four years ago.

the content $\left(\mathrm{g} \mathrm{kg}^{-1}\right)$ of the soil mass under the land uses, at each depth studied. The pattern soil mass was obtained multiplying the thickness of each layer $(\mathrm{m})$ by its soil bulk density $\left(\mathrm{kg} \mathrm{dm}^{-3}\right)$, soil volume $\left(\mathrm{dm}^{3}\right)$. Accumulated stocks were calculated to the layers of $0.0-0.1,0.0-0.2,0.00-0.4,0.0-0.6$ and $0-1.0 \mathrm{~m}$.
A correction of $\mathrm{C}$ and $\mathrm{N}$ stocks in SOM fractions was performed to minimize the compacting effect of soils caused by the machine traffic (mechanical preparation and eucalypt harvest operations), according to Sisti et al. (2004). Thus, the $\mathrm{C}$ and $\mathrm{N}$ stocks in the SOM fractions were estimated as the total C and $\mathrm{N}$ 
content, in the same soil mass present in a $0.0-1.0-\mathrm{m}$ layer of the native vegetation. For this, the $\mathrm{C}$ and $\mathrm{N}$ stocks were calculated subtracting the $\mathrm{C}$ and $\mathrm{N}$ content of the extra soil weight in the deepest layer sampled (0.6-1.0 m) for each profile, which can be expressed according to the Equation 1:

$$
\mathrm{Cs}=\sum_{i=1}^{\mathrm{n}-1} \mathrm{CTi}+\left[\mathrm{MTn}-\left(\sum_{i=1}^{\mathrm{n}} \mathrm{MTi}-\sum_{\mathrm{i}=1}^{\mathrm{n}} \mathrm{MSi}\right)\right] * \mathrm{CTn}
$$

where: $C s$ is the total C stock, corrected for the soil mass of a reference area; $\sum_{i=1}^{n-1} C T i$ is the sum of $C$ stocks of soil from the first until before the last soil layer sampled, in the treatment considered $\left(\mathrm{Mg} \mathrm{ha}^{-1}\right) ; M T n$ is the soil mass of the last soil layer sampled in the treatment $\left(\mathrm{Mg} \mathrm{ha}^{-1}\right) ; \sum_{\mathrm{i}=1}^{\mathrm{n}} \mathrm{MTi}$ is the sum of the total soil mass sampled under the treatment $\left(\mathrm{Mg} \mathrm{ha}^{-1}\right) ; \sum_{\mathrm{i}=1}^{\mathrm{n}} \mathrm{MSi}$ is the sum of total mass of soil sampled in the reference area $\left(\mathrm{Mg} \mathrm{ha}^{-1}\right)$; and CTn is soil C content in the last soil layer sampled ( $\mathrm{Mg} \mathrm{Mg}^{-1}$ soil).

The results were submitted to analysis of variance (ANOVA), considering a systematic design with four replicates. The averages of the treatments were compared with the Tukey's test $(p \leq 0.05)$ using the statistical Software SISVAR.

\section{RESULTS}

The reform management of eucalypt plantation planted 13 years ago (Euc R0) led to increases $(p \leq 0.05)$ in total organic C stocks (TOC) in all soil layers after 1 year, with increases of 128 and $185 \%$ in TOC stocks in the soil layers of 0.0-0.1 and 0.0-1.0 m, respectively (Figure 1a). However, after 2 years of the reform management, it was observed that the TOC stock returned to the stock level observed in eucalypt plantation with 13 -years-old of first rotation (soil layers 0.0-0.10 and 0.0-1.0-m).

Total nitrogen (TN) stocks did not change after 1 year of reform management in the 0.0-0.1-m and 0.0-0.4-m soil layers. After 2 years of the reform management, there were increases of NT stocks in the 0.0-0.4-m layer in relation to the first eucalypt rotation (13-years-old) (Figure 1b). After 4 years of reform management, TN stocks were similar to those observed in the first eucalypt rotation to all soil layers. In the $0.0-1.0-\mathrm{m}$ soil layer, no differences over time were observed in TN stocks
(Figure $1 \mathrm{~b})$. The $\mathrm{C}: \mathrm{N}$ ratio was higher after 1 year of reform management in the $0.0-0.1-\mathrm{m}$ soil layer, and subsequently decreased, reaching $\mathrm{C}: \mathrm{N}$ ratio similar to the first eucalypt rotation (Figure 1c). However, in the 0.0-1.0-m soil layer the C:N ratio was lower than that observed in the 1 year after the reform management only at 4 years post-reform management (Figure 1c).

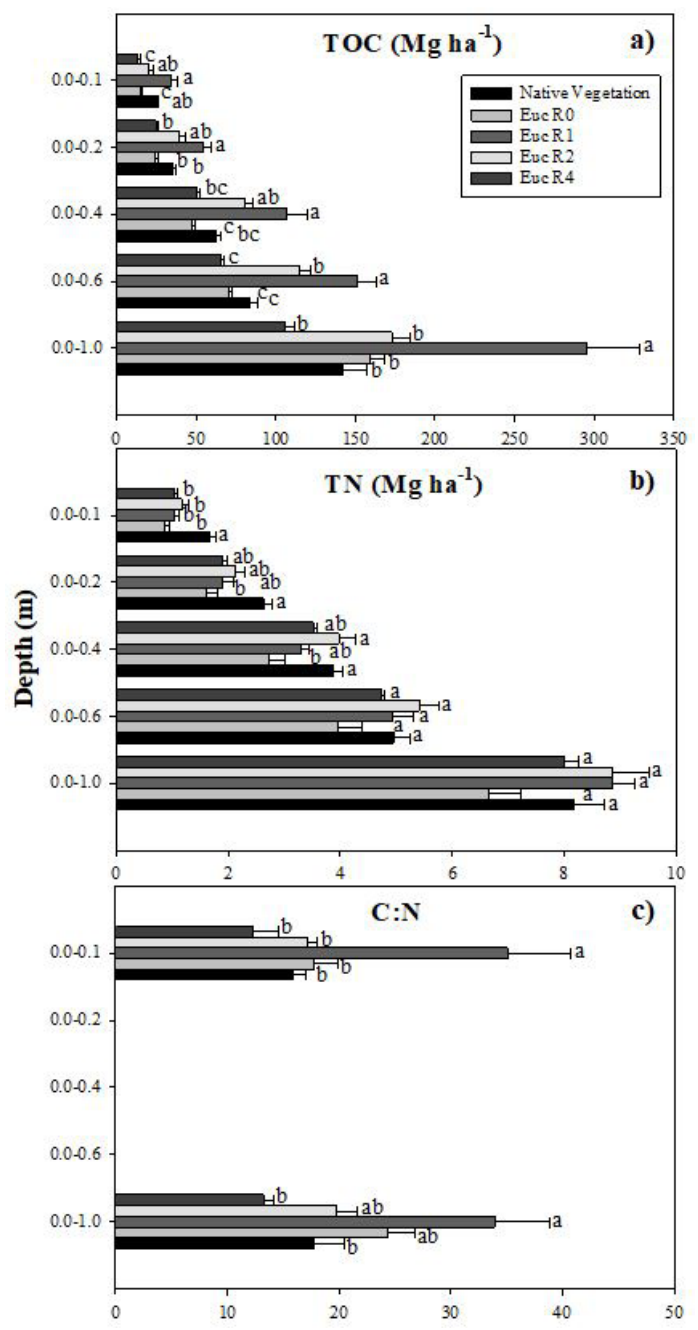

Figure 1. Total Organic Carbon stocks (TOC; a), total nitrogen (TN; b), and C:N ratio (c) in Ultisol from east of Rio Grande do Sul state under native vegetation, eucalypt plantation with 13 years implemented in native vegetation area that has never been reformed (Euc R0), and eucalypt plantation with 1 (Euc R1), 2 (Euc R2), and 4 years post-reform management (Euc R4). Means of uses with the same lowercase letters within each soil layer are not statistically different by Tukey's test at $5 \%$ of significance. The bars represent the standard errors $(\mathrm{n}=4)$. 
The FA-C stocks increased after 1 and 2 years of reform management in all soil layers, with the exception of 0.0-1.0-m layer, for which no change was observed (Figure 2a). The increases of FA-C stocks in the $0.0-0.6-\mathrm{m}$ soil layer were 8.27 and $14.75 \mathrm{Mg} \mathrm{ha}^{-1}$ after 1 and 2 years of reform management, respectively.

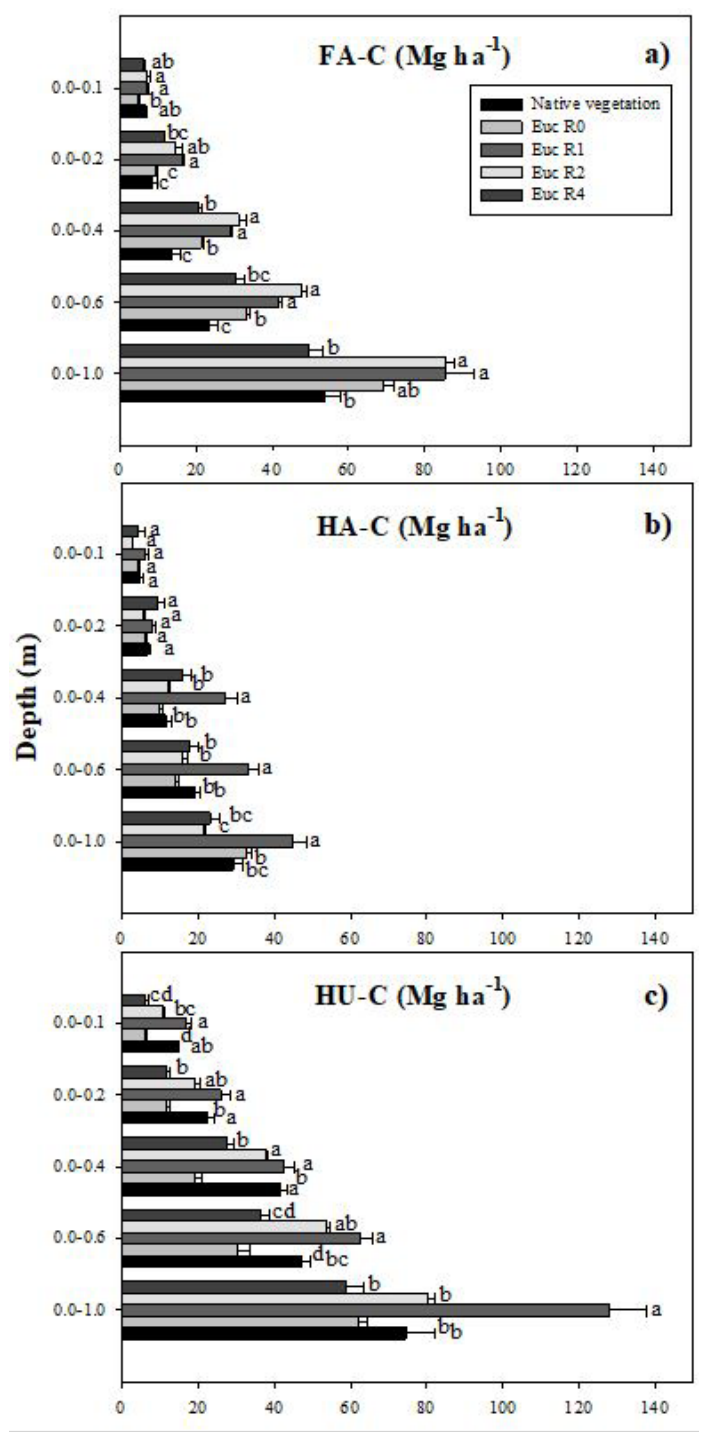

Figure 2. Stocks of $\mathrm{C}$ associated with fulvic acids fractions (FA-C; a), humic acid (HA-C; b), and humin (HU-C; c) in Ultisol from east of the Rio Grande do Sul state under the native field, eucalyptus with 13 years implemented in native pasture area that has never been reformed (Euc R0), and eucalyptus with 1 (Euc R1), 2 (Euc R2), and 4 years post-reform (Euc R4). Means of uses with the same lowercase letters within each soil layer are not statistically different by Tukey's test at 5\% of significance. The bars represent the standard errors $(n=4)$.
The FA-N stocks were altered by reform management only at the soil surface layers (Figure $3 \mathrm{a}$ ).

In the soil superficial layers (0.0-0.1 and 0.1-0.2-m), there were no significant differences in the HA-C stocks, while in the $0.0-1.0-\mathrm{m}$ layer were observed higher stocks in the eucalypt plantation reformed 1 year ago

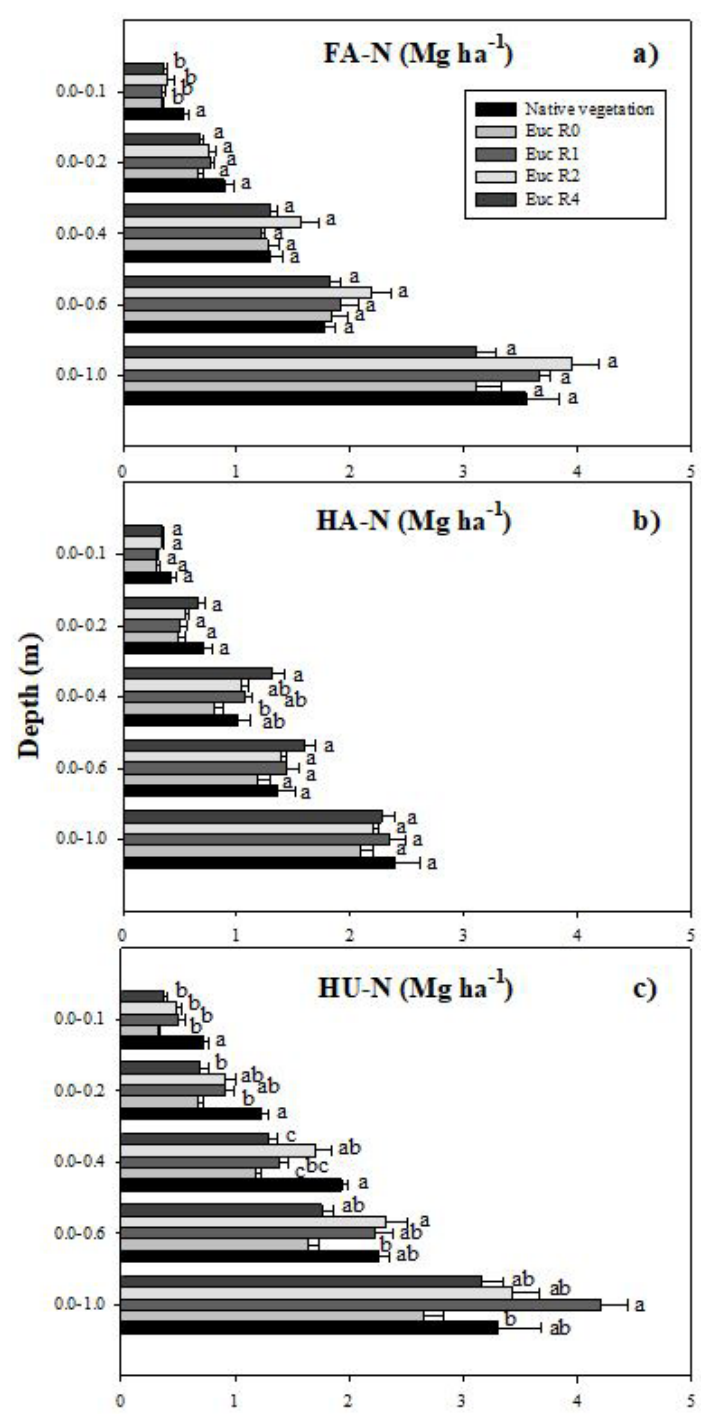

Figure 3. Stocks of $\mathrm{N}$ associated with fulvic acids fractions (FA-N; a), humic acid (HA-N; b), and humin (HU-N; c) in Ultisol from east of the Rio Grande do Sul state under native field, eucalyptus with 13 years implemented in native pasture area that has never been reformed (Euc R0), and eucalyptus with 1 (Euc R1), 2 (Euc R2), and 4 years post-reform (Euc R4). Means of uses with the same lowercase letters within each soil layer are not statistically different by Tukey's test at $5 \%$ of significance. The bars represent the standard errors $(n=4)$. 
(Figure 2b). In the 0.0-1.0-m layer, the differences were more accentuated, with decreases in HA-C stocks of $11.45 \mathrm{Mg} \mathrm{ha}^{-1}$ after 2 years of reform management. No differences were observed between HA-N stocks in most soil layers of the chronosequence (Figure $3 \mathrm{~b}$ ).

After 1 and 2 years, the reform management of eucalypt plantations provided more increases in $\mathrm{HU}-\mathrm{C}$ stocks to the 0.0-0.10-m soil layer than the first eucalypt rotation (10.57 and 4.54 $\mathrm{Mg} \mathrm{ha}^{-1}$, respectively); while in the 0.0-1.0-m soil layer there were increments of $65.95 \mathrm{Mg} \mathrm{ha}^{-1}$ after 1 year of reform management (Figure 2c). An increase of $1.56 \mathrm{Mg} \mathrm{ha}^{-1}$ of HU-N after 1 year of reform management was observed to the 0.0-1.0-m soil layer; while 2 and 4 years after reform management the N-HU stocks did not differ from that observed prior to the reform management (Figure 3c).

Negative impact on LOM-C stocks was observed after 4 years of reform in the relation of native vegetation to the $0.0-0.6$ and $0.0-1.0-\mathrm{m}$ soil layers (loss of $58.7 \%$ and $58.0 \%$, respectively) (Figure $4 \mathrm{a}$ ). The LOM-N stocks did not present statistical differences in the soil layers evaluated over time after reform management (Figure 4b). The LOM-C:N ratio did not change in the 0.0-0.1-m soil layer over the post-reform time; while to the $0.0-1.0-\mathrm{m}$ soil layer there were reductions in the 13-year eucalypt plantation and 1-year reform, compared to native vegetation (Figure 4c).

The MB-C (0.0-0.2-m soil layer) and MB-N (0.0-0.1-m soil layer) stocks increased at 13 years after the eucalypt implantation compared with native vegetation area (Figure 5a, b). However, 1 year after reform management, the $\mathrm{MB}-\mathrm{C}$ stock decreased by an average of $66.6 \%$ in the $0.0-0.2-\mathrm{m}$ soil layer (Figure $5 \mathrm{a}$ ). After 2 years of reform, there was a decrease in the $\mathrm{MB}-\mathrm{N}$ stocks (43.9\%) to the 0.0-0.1-m soil layer. However, there was the recovery of MB-N stocks after 4 years of reform management (Figure $5 \mathrm{~b}$ ). The MB-C:N ratio, to the $0.0-0.1$ and $0.0-1.0-\mathrm{m}$ soil layers did not change for the different soil uses (Figure $5 \mathrm{c}$ ).

\section{DISCUSSION}

In this study, it was verified that 1-year after reform management of eucalypt plantation (0.0-1.0-m soil layer), there is an expressive increase in the TOC stock, and in most of $\mathrm{C}$ associated with humic substances (HA-C and HU-C). Even in this period, expressive reductions in the MB-C stocks in the 0.0-0.1-m soil layer was already observed. Cotrufo et al. (2013), studying the origin of stabilized SOM, verified that a major contribution to $\mathrm{C}$ associated with minerals comes from labile constituents of plants that after microbial transformation was stabilized in the soil

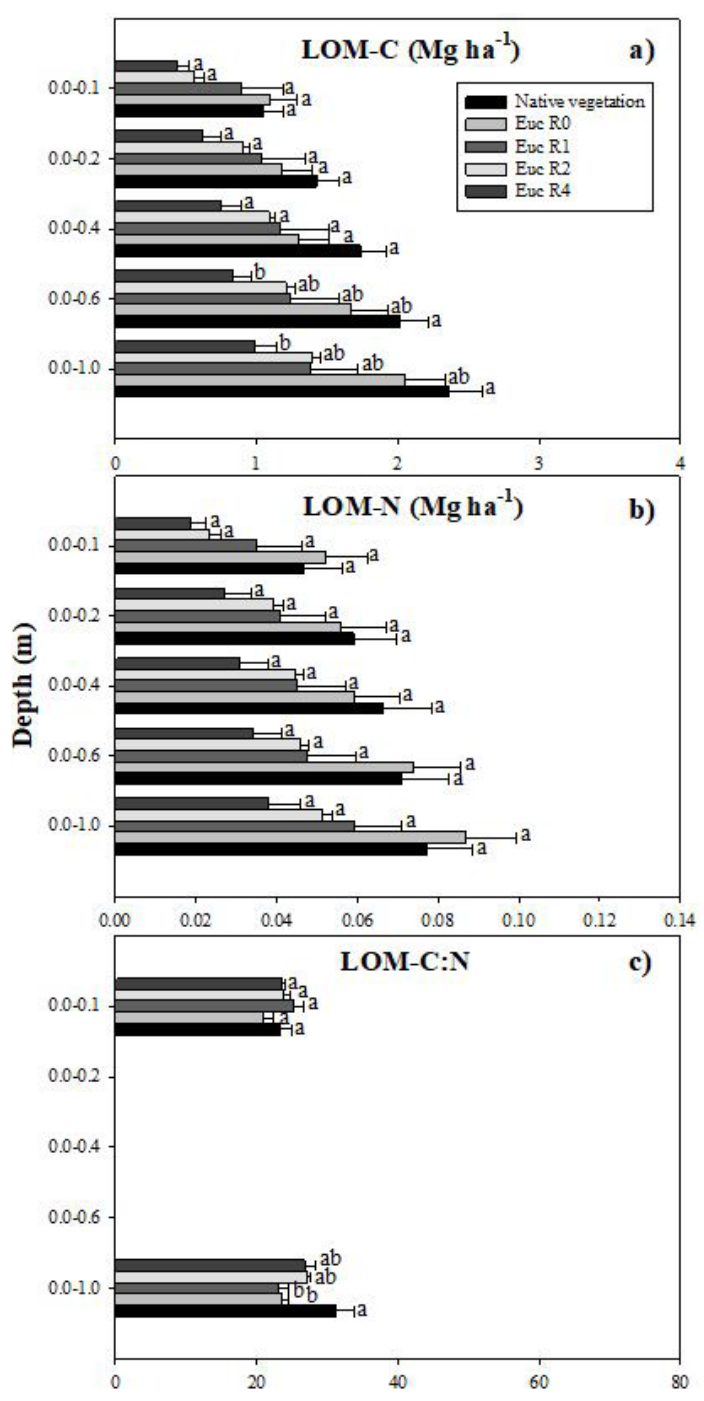

Figure 4. Stocks of C (LOM-C; a), N (LOM-N; b), and $\mathrm{C}: \mathrm{N}$ rate (LOM-C:N; c) associated with the light organic matter in Ultisol from east of the Rio Grande do Sul state under native field, eucalyptus with 13 years implemented in native pasture area that has never been reformed (Euc R0), and eucalyptus with 1 (Euc R1), 2 (Euc R2), and 4 years post-reform (Euc R4). Means of uses with the same lowercase letters within each soil layer are not statistically different by Tukey's test at $5 \%$ of significance. The bars represent the standard errors $(n=4)$. 


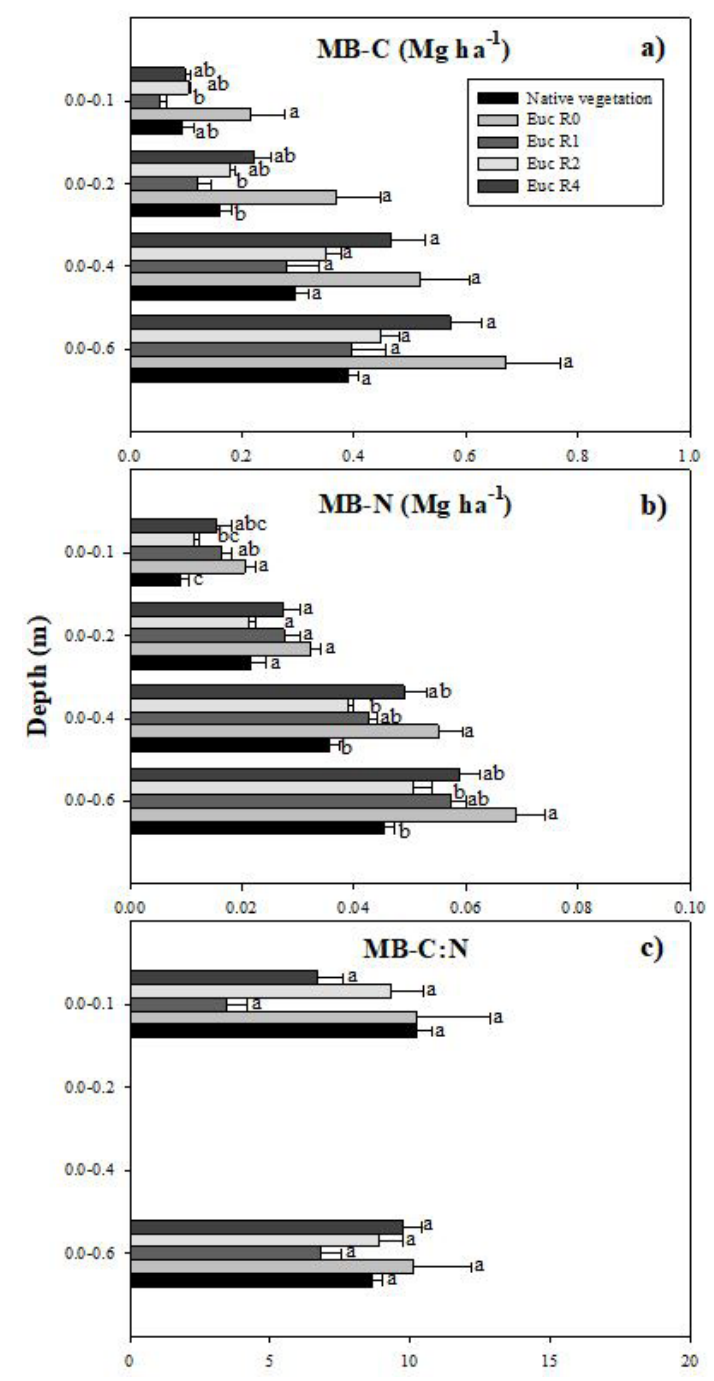

Figure 5. Stocks of C (MB-C; a), N (MB-N; b), and $\mathrm{C}: \mathrm{N}$ rate (MB-C:N; c) associated with microbial biomass in Ultisol from east of the Rio Grande do Sul state under native field, eucalyptus with 13 years implemented in native pasture area that has never been reformed (Euc R0), and eucalyptus with 1 (Euc R1), 2 (Euc R2), and 4 years post-reform (Euc R4). Means of uses with the same lowercase letters within each soil layer are not statistically different by Tukey's test at $5 \%$ of significance. The bars represent the standard errors $(\mathrm{n}=4)$.

mineral matrix. This fact corroborates to higher HU-C stocks (fraction of MOS associated with minerals) in the present study (Figure 2c). Additionally, the higher soil clay content under eucalypt reformed 1 year ago is also an important factor to contribute for higher $\mathrm{C}$ stock of these more recalcitrant fractions (Mathers et al., 2003; Jindaluang et al., 2013).
Another important factor to higher $\mathrm{C}$ stock after 1 year of reform are the contributions of the roots decomposition derived from the previous planting allied to the growth and development of the new root system of introduced plants. In eucalypt plantations, a large volume of roots was observed in deep soil layers already in the first year of rotation (Laclau et al., 2013). Rasse et al. (2005) observed that the input of $40 \%$ of C via roots was recovered as $\mathrm{C}$ of SOM, while the input of $\mathrm{C}$ by shoot contributed only with $20 \%$.

The contribution of roots to soil C occurs mainly via rhizodeposition (lysates, exudates, secretions and mucilages) and by the root biomass. The $\mathrm{C}$ temporarily immobilized by plants in the root biomass during its life cycle has significant importance, since studies in Spain have shown that about 35\% of biomass from 9-year-old eucalypt plants is in the form of roots (Herrero et al., 2014), contributing significantly to the input of $\mathrm{C}$ into the soil.

Pegoraro et al. (2011), studying eucalypt plantations at the end of the $4^{\text {th }}$ rotation (at 7-years-old), in Espírito Santo state, observed transfer average of $10 \mathrm{Mg} \mathrm{ha}^{-1}$ from root-derived $\mathrm{C}$ of previous rotation to SOM fractions 1 year after harvest. The soil $\mathrm{C}$ stocks increased until the eucalypt plantation reached 3 years old, with the highest stocking observed in the 0.6-m soil layer, an area that would have a greater accumulation of thick and old roots.

Mack et al. (2014), studying pine plantations, found an increase in soil C contents in the $0.4-0.6$-m soil layer after 15 years, compared with plantations from which the harvest residues were removed. This fact suggests that, besides the contribution of roots, there also could have a translocation of organic leachates from residues and organic matter desorbed from soil layers overlying the current one. The gains in soil C stocks at the end of a rotation had a greater magnitude in the conducted plantation than those reformed, demonstrating the importance of the disturbance reduction in the area at the time of the plantations reform management.

The higher $\mathrm{C}$ stock associated with soil microbial biomass was found in the soil under eucalypt at 13 years old (0.0-0.2-m soil layer). Lupatini et al. (2013) found a $\mathrm{C}$ content associated with the microbial community in eucalypt forest $78 \%$ higher than that found in the native field. The authors attributed the result mainly to the differences in the type of vegetation that alters the 
community of decomposing fungi. In fact, in recent meta-analysis regarding the substitution of native forests by exotic species in areas under river basin influence, Ferreira et al. (2016) detected a strong effect of low quality in eucalypt litter, reducing the decomposition efficiency and the microbial decomposing community profile.

The $\mathrm{C}$ stock associated with light organic matter reduced after four years of reform management (0.0-0.1-m soil layer) in relation to the native vegetation. This occurred probably due to the disturbance caused by the operation, although there was a large harvest residue input. The presence of harvest residue in the area favors the contribution of more labile organic matter (Jesus et al., 2015), and may trigger the so-called priming effect (Kuzyakov, 2010), which stimulated the faster decomposition of LOM by the soil microbes (Fontaine et al., 2007).

Thus, the management of eucalypt plantations with short-rotation and more frequent reforms does not seem to allow sufficient time for the recovery of SOM, due to its continuous decomposition and the low contribution of the litter in the initial years after the reform management. SOM fractions such as LOM and MB can be considered as early indicators of SOM changes. The fast response of MB and LOM to changes in soil has been evidenced by others authors (Fernandes et al., 2012; Barreto et al., 2014). The trend of the faster reestablishment of the microbial population over time (after four years of reform management) points to the dynamism of this fraction. After harvesting the eucalypt residues left in the area, readily degradable compounds are quickly metabolized, while the more lignified components (bark and branches) remain in the soil due its biochemical stability (recalcitrance). Biochemical cycling via litter deposition only started after approximately two years. This fact implies in little and discontinuous substrate contribution to $\mathrm{MB}$ in the first two years. In addition, temperature and humidity oscillations because of soil exposure in this period are larger due to the small size of the plants.

\section{CONCLUSIONS}

The reform management in eucalypt plantation promotes a significant increase in the TOC, HA-C, HU-C and HU-N stocks after one year of reform (0.0-1.0-m soil layer) and expressive reductions in MB-C (0.0-0.2-m soil layer). However, after a period of reform management (four years), there is a decrease in all more stable SOM fractions stocks, while the C and $\mathrm{N}$ stocks associated with $\mathrm{MB}$ tend to reestablish.

\section{ACKNOWLEDGEMENTS}

The authors thank the National Council for Scientific and Technological Development (Conselho Nacional de Desenvolvimento Científico e Tecnológico - CNPq) for their continuous financial support, the CMPC forestry company for the use of the experimental area and, especially, the engineer Elias Frank Araújo for assisting with the careful selection of the study sites and the collection of soil samples.

\section{SUBMISSION STATUS}

Received: 8 june, 2017

Accepted: 26 oct., 2017

\section{CORRESPONDENCE TO}

\section{Rafael da Silva Teixeira}

Departamento de Solos, Universidade Federal de Viçosa - UFV, Av. PH Rolfs, s/n, CEP 36570-000, Viçosa, MG, Brasil

e-mail: teixeiramarky@yahoo.com.br

\section{REFERENCES}

Amiro BD, Barr AG, Barr JG, Black TA, Bracho R, Brown $\mathrm{M}$ et al. Ecosystem carbon dioxide fluxes after disturbance in forests of North America. Journal of Geophysical Research Biogeosciences 2000; 115(G4).

Barreto PAB, Gama-Rodrigues EF, Gama-Rodrigues AC. Carbono das frações da matéria orgânica em solos sob plantações de eucalipto de diferentes idades. Scientia Forestalis 2014; 42: 581-590.

Chatterjee A, Vance GF, Pendall E, Stahl PD. Timber harvesting alters soil carbon mineralization and microbial community structure in coniferous forests. Soil Biology \& Biochemistry 2008; 40(7): 1901-1907. http://dx.doi. org/10.1016/j.soilbio.2008.03.018.

Cotrufo MF, Wallenstein M, Boot C, Denef K, Paul E. The Microbial Efficiency-Matrix Stabilization (MEMS) framework integrates plant litter decomposition with soil organic matter stabilization: do labile plant inputs form stable soil organic matter? Global Change Biology 2013; 
19(4): 988-995. http://dx.doi.org/10.1111/gcb.12113. PMid:23504877.

Dias MS Jr, Fonseca S, Araújo CF Jr, Silva AR. Soil compaction due to forest harvest operations. Pesquisa Agropecuária Brasileira 2007; 42(2): 257-264. http://dx.doi. org/10.1590/S0100-204X2007000200015.

Faria GE, Barros NF, Silva IR, Novais RF, Paiva AO. Carbono orgânico total e frações da matéria orgânica em diferentes distâncias da cepa de eucalipto. Cerne 2008; 14: 259-266.

Fernandes MM, Carvalho MGC, Araujo JMR, Melo FR, Silva CA, Sampaio FMT et al. Matéria orgânica e biomassa microbiana em plantios de eucalipto no Cerrado Piauiense. Floresta e Ambiente 2012; 19(4): 453-459. http://dx.doi. org/10.4322/floram.2012.061.

Ferreira GW, Soares BEM, Oliveira FCC, Silva IR, Dungait JAJ, Souza IF et al. Nutrient release from decomposing Eucalyptus harvest residues following simulated management practices in multiple sites in Brazil. Forest Ecology and Management 2016; 70: 1-11. http://dx.doi.org/10.1016/j. foreco.2016.03.047.

Fontaine S, Barot S, Barre P, Bdioui N, Mary B, Rumpel C. Stability of organic carbon in deep soil layers controlled by fresh fcarbon supply. Nature 2007; 450(7167): 277-280. http://dx.doi.org/10.1038/nature06275. PMid:17994095.

Food and Agriculture Organization - FAO. Planted forests in sustainable forest management. a statement of principles. Rome; 2010.

Herrero C, Juez L, Tejedor C, Pando V, Bravo F. Importance of root system in total biomass for Eucalyptus globulus in northern Spain. Biomass and Bioenergy 2014; 67: 212222. http://dx.doi.org/10.1016/j.biombioe.2014.04.023.

Indústria Brasileira de Árvores - IBÁ. Relatório anual de atividades: ano base 2015. São Paulo; 2016.

Islam KR, Weil RR. Microwave irradiation of soil for routine measurement of microbial biomass carbon. Biology and Fertility of Soils 1998; 27(4): 408-416. http://dx.doi. org/10.1007/s003740050451.

Jesus GL, Silva IR, Almeida LFJ, Santos MA, Leite FP, Neves JCL. Produtividade do eucalipto, atributos físicos do solo e frações da matéria orgânica influênciadas pela intensidade de tráfego e resíduos de colheita. Revista Brasileira de Ciência do Solo 2015; 39(4): 1190-1203. http:// dx.doi.org/10.1590/01000683rbcs20140494.

Jindaluang W, Kheoruenromne I, Suddhiprakarn A, Singh BP, Singh B. Influence of soil texture and mineralogy on organic matter content and composition in physically separated fractions soils in Thailand. Geoderma 2013; 195-196: 207-219. http://dx.doi.org/10.1016/j. geoderma.2012.12.003.

Kuzyakov Y. Priming effects: Interactions between living and dead organic matter. Soil Biology \& Biochemistry 2010; 42(9): 1363-1371. http://dx.doi.org/10.1016/j. soilbio.2010.04.003.
Laclau JP, Nouvellon Y, Reine C, Gonçalves JLM, Krushe AV, Jourdan C et al. Mixing eucalyptus and Acacia trees leads to fine root over-yielding and vertical segregation between species. Oecologia 2013; 172(3): 903-913. http:// dx.doi.org/10.1007/s00442-012-2526-2. PMid:23180423.

Lupatini M, Jacques RJS, Antoniolli ZI, Suleiman AKA, Fulthorpe RR, Roesch LFW. Land-use change and soil type are drivers of fungal and archaeal communities in the Pampa biome. World Journal of Microbiology \& Biotechnology 2013; 29(2): 223-233. http://dx.doi. org/10.1007/s11274-012-1174-3. PMid:23054698.

Mack J, Hatten J, Sucre E, Roberts S, Leggett Z, Dewey J. The effect of organic matter manipulations on site productivity, soil nutrients, and soil carbon on a southern loblolly pine plantation. Forest Ecology and Management 2014; 326: 25-35. http://dx.doi.org/10.1016/j.foreco.2014.04.008.

Maluf JRT. Nova classificação climática do estado do Rio Grande do Sul. R Bras Agrometeorol. 2000; 8: 141-150.

Mathers NJ, Mendham DS, O'Connell AM, Grove TS, Xu Z, Saffigna PG. How does residue management impact soil organic matter composition and quality under Eucalyptus globulus plantations in southwestern Australia? Forest Ecology and Management 2003; 179(1-3): 253-267. http:// dx.doi.org/10.1016/S0378-1127(02)00527-3.

Moreno JA. Clima do Rio Grande do Sul. Porto Alegre: Secretaria da Agricultura; 1961.

Nave LE, Vance ED, Swanston CW, Curtis PS. Harvest impacts on soil carbon storage in temperature forests. Forest Ecology and Management 2010; 259(5): 857-866. http://dx.doi.org/10.1016/j.foreco.2009.12.009.

Ndaw SM, Gama-Rodrigues AC, Gama-Rodrigues ES, Sales KRN, Rosado AS. Relationships between bacterial diversity, microbial biomass, and litter quality in soils under different plant covers in northern Rio de Janeiro State, Brazil. Canadian Journal of Microbiology 2009; 55(9): 1089-1095. http://dx.doi.org/10.1139/W09-066. PMid:19898551.

Oliveira AH, Silva MLN, Curi N, Avanzi JC, Klinke G No, Araújo EF. Water erosion in soils under eucalyptus forest as affected by development stages and management systems. Ciência e Agrotecnologia 2013; 37(2): 159-169. http://dx.doi.org/10.1590/S1413-70542013000200007.

Pegoraro RF, Silva IR, Novais RF, Barros NF, Fonseca $S$, Dambroz CS. Estoques de carbono e nitrogênio nas frações da matéria orgânica em argissolo sob eucalipto e pastagem. Ciência Florestal 2011; 21(2): 261-273. http:// dx.doi.org/10.5902/198050983230.

Rasse DP, Rumpel C, Dignac MF. Is soil carbon mostly root carbon? Mechanisms for a specific stabilization. Plant and Soil 2005; 269(1-2): 341-356. http://dx.doi. org/10.1007/s11104-004-0907-y.

Sisti CPJ, Santos HP, Kohhann R, Alves BJR, Urquiaga S, Boddey RM. Change in carbon and nitrogen stocks in soil 
under 13 years of conventional or zero tillage in southern Brazil. Soil \& Tillage Research 2004; 76(1): 39-58. http:// dx.doi.org/10.1016/j.still.2003.08.007.

Sohi SP, Mahieu N, Arah JRM, Powlson DS, Madari B, Gaunt JL. A procedure for isolating soil organic matter fractions suitable for modeling. Soil Science Society of America Journal 2001; 65(4): 1121-1128. http://dx.doi. org/10.2136/sssaj2001.6541121x.

Strömgren M, Egnell G, Olsson BA. Carbon stocks in four forest stands in Sweden 25 years after harverting of slash and stumps. Forest Ecology and Management 2013; 290: 59-66. http://dx.doi.org/10.1016/j. foreco.2012.06.052.

Swift RS. Method for extraction of IHSS soil fulvic and humic acids. In: Sparks DL, Parks DL, Page AL, Helmke PA, Loeppert RH, Soltanpour PN et al., editors. Methods of soil analysis. Part 3: chemical methods. Madison: Soil Science Society American Books; 1996. p. 1018-1020.

Tedesco HJ, Volkweiss SJ, Bohnen H. Análises de solo, plantas e outros materiais. Porto Alegre: Universidade Federal do Rio Grande do Sul; 1985. 50 p. (Boletim Técnico; no. 5).

Versini A, Nouvellon Y, Laclau J-P, Kinana A, Mareschal $\mathrm{L}$, Zeller B et al. The manipulation of organic residues affects tree growth and heterotrophic $\mathrm{CO}_{2}$ efflux in a tropical eucalyptus plantation. Forest Ecology and Management 2013; 301: 79-88. http://dx.doi.org/10.1016/j. foreco.2012.07.045.

Yeomans JC, Bremner JM. A rapid and precise method for routine determination of organic carbon in soil. Communications in Soil Science and Plant Analysis 1988; 13: 146. 